\title{
Brachioproctic eroticism and transmission of retrovirus associated with acquired immune deficiency syndrome (AIDS)
}

\author{
BASIL DONOVAN,* BRETT TINDALL, $\dagger$ AND DAVID COOPER $\ddagger$ (FOR THE SYDNEY AIDS \\ STUDY GROUP)
}

From the *Taylor Square Private Clinic, the †Centre for Immunology, St Vincent's Hospital, and the $\ddagger$ National Health Medical Research Centre for Clinical and Epidemiological AIDS Research, University of New South Wales, Sydney, Australia

SUMMARY A case of transmission of the acquired immune deficiency syndrome (AIDS) associated retrovirus (ARV) by brachioproctic eroticism is described.

\section{Introduction}

The lymphocytotropic retroviruses variously known as lymphadenopathy associated virus (LAV), ${ }^{1}$ human T cell lymphotropic virus type III (HTLV-III), ${ }^{2}$ and the acquired immune deficiency syndrome (AIDS) associated retrovirus (ARV) ${ }^{3}$ are now well documented as the cause of AIDS and related conditions. These viruses have been isolated from blood, ${ }^{1-3}$ semen, ${ }^{4}$ saliva, ${ }^{5}$ breast milk, ${ }^{6}$ and tears. ${ }^{7}$ The major routes of transmission documented to date include anal intercourse, ${ }^{8}$ vaginal intercourse, ${ }^{9}$ transfusion of blood ${ }^{10}$ and blood products, ${ }^{11}$ sharing of needles and syringes by intravenous drug users, ${ }^{12}$ transmission from mother to child in the perinatal period, ${ }^{13}$ and artificial insemination. ${ }^{14}$ Reports of needlestick transmission in

Address for reprints: Dr B Donovan, Taylor Square Private Clinic, 302 Bourke Street, Sydney, New South Wales 2010, Australia

Accepted for publication 18 March 1986

\section{SYDNEY AIDS STUDY GROUP}

Consultants: A I Adams, D G Fox, G Berry, J Dykes.

Project principal investigators: D A Cooper, J Gold.

Centre for Immunology, St Vincent's Hospital, Sydney: R Penny,

P Borrow, G Chapman, L Hurren, A Imrie, C Katakouzinos, S

Kehrer, H McCabe, A Malcolm, M North, E Schreurs, G Smith, H

Smith, B Tindall, $\mathbf{R}$ Wilson

School of Public Health and Tropical Medicine, Sydney University: J Burcham

Albion Street Centre, Sydney Hospital: M Anns, D Grant, C Kronenberg, M Perdices, P Todd.

STD Centre, Sydney Hospital: R Philpot, R Jones, J Roberts

Participating medical practitioners: T G Barnes, P Brooke, B

Donovan, R Finlayson, P Haynes, R Lovett, H M Michelmore, $\mathrm{K}$ Mutimer, R Price. a health care worker ${ }^{15}$ and suggestive of transmission via breast feeding ${ }^{16}$ have also appeared. We describe a probable case of transmission of the AIDS associated retrovirus (ARV) by brachioproctic eroticism ("fisting").

\section{Case report}

A 43 year old homosexual man was recruited into the Sydney AIDS prospective study ${ }^{17}$ in August 1984 . His medical history included solar keratoses with ulceration on his face and the back of his hands for many years, acute hepatitis B in 1972, and a syphilis chancre on the back of his left hand in 1982. He had no other history of sexually transmissible diseases (STDs). On enrolment and in April 1985 he was symptomless with no lymphadenopathy or hepatosplenomegaly. On both occasions antibodies to ARV by immunofluorescence (IF), enzyme linked immuno-sorbent assay (ELISA), and radioimmunoprecipitation assay (RIPA) were not detected in his serum, and his $\mathrm{T}$ cell subsets were normal.

In mid June 1985 the patient suffered sudden onset of lethargy and passed dark urine and pale stools for one day. Eleven days later he developed generalised myalgias and arthralgias, fevers, night sweats, severe malaise, and a diffuse swelling of the right buccal mucosa. These symptoms settled during three weeks, but he became depressed and irritable and developed a non-productive cough and nasal congestion that persisted for seven weeks. In August 1985 he developed generalised lymphadenopathy, and on review in September physical examination showed hepatosplenomegaly, several crusted solar keratoses and an atrophic chancre scar on the left hand, truncal 
prurigo, and patches of atrophic papillae on his tongue. Investigations in early July showed mild lymphopenia, an erythrocyte sedimentation rate (Westergen) of 14 $\mathrm{mm}$ in the first hour, slightly raised transaminase activity, and a negative test for antibodies to ARV. In August his serum was positive for antibodies to ARV (by ELISA and IF). The blood film showed eosinophilia $\left(870 \times 10^{6} / 1\right)$ and atypical mononuclear cells. Heterophilic antibodies were detected, but IgM antibodies to cytomegalovirus, Epstein-Barr virus, and Toxoplasma gondii were not found. The laboratory data showing changes in ARV antibody and $T$ cell subsets in this patient are presented in the table.

The patient's regular sexual partner had a continual history of lethargy and night sweats from 1983. In 1983 he was noted to have generalised lymphadenopathy and hepatosplenomegaly. He was treated for anal condylomata in 1985 . Testing in 1983 had shown anergy, an inverted ratio of T4 to T8 cells $(0 \cdot 80)$, and moderately raised serum transaminase activity. In August 1984 antibodies to ARV were detected in his serum by IF, ELISA, and RIPA, and the results of T cell subset testing are shown in the table.

The couple's sexual practices since early 1984 consisted of "dry" kissing, mutual masturbation to ejaculation, and brachioproctic eroticism (insertion of the patient's unprotected left hand at least $15 \mathrm{~cm}$ into his partner's rectum). His partner had noted occasional slight rectal bleeding after this practice, which occurred about once a week. The patient disliked anogenital, orogenital, and oroanal sexual practices and had not engaged in these for more than 18 months before seroconversion. $\mathrm{He}$ has neither used intravenous drugs nor received blood products.

\section{Discussion}

We think that the patient probably contracted ARV infection through the practice of brachioproctic eroticism between April and June 1985, after a long potential exposure to the retrovirus. The acute illness, which began in June 1985, had similar features to other illnesses associated with seroconversion. ${ }^{18}$

Though insertive and receptive brachioproctic eroticism have been significantly associated with ARV seropositivity in homosexual men, ${ }^{19} 20$ most men who engage in this practice also engage in anogenital and orogenital sex. Brachioproctic eroticism may indicate a high degree of involvement in homosexual practices. This patient, however, had avoided penetrating sexual practices other than brachioproctic eroticism for a long time, which was confirmed by the negative history of STDs except for hepatitis B and the chancre on his hand.

Though epidemiological evidence strongly suggests that ARV is not transmitted through intact skin, this patient had persistent keratotic ulcers on his hand, which had been frequently and directly exposed to his partner's anorectal mucosa and probably blood for almost two years. In addition, he had a history of transmission of Treponema pallidum by identical means. It is not impossible, however, that ARV could have been transmitted in this instance by kissing or by contact with his partner's semen either through his hand lesions or through accidental mucosal contact.

TABLE Laboratory data on reported patient and his sexual partner and 63 controls

\begin{tabular}{|c|c|c|c|c|c|}
\hline Date & $\begin{array}{l}\text { Antibodies } \\
\text { to } A R V\end{array}$ & $\begin{array}{l}\text { Lymphocyte } \\
\text { count }\left(\times 10^{6} / l\right)\end{array}$ & $\begin{array}{l}T 4 \text { cells } \\
\left(\times 10^{6} / l\right)\end{array}$ & $\begin{array}{l}\text { T8 cells } \\
\left(\times 10^{6} / l\right)\end{array}$ & $\begin{array}{l}\text { Ratio of } \\
\text { T4 to T8 }\end{array}$ \\
\hline \multicolumn{6}{|l|}{ Patient } \\
\hline $\begin{array}{l}\text { August } 1984 \\
\text { April } 1985 \\
*\end{array}$ & $\begin{array}{l}\text { Negative } \\
\text { Negative }\end{array}$ & $\begin{array}{l}2400 \\
2300\end{array}$ & $\begin{array}{r}1100 \\
920\end{array}$ & $\begin{array}{l}340 \\
300\end{array}$ & $\begin{array}{l}3 \cdot 20 \\
3 \cdot 10\end{array}$ \\
\hline $\begin{array}{l}\text { July } 1985 \\
\text { September } 1985 \\
\text { December } 1985\end{array}$ & $\begin{array}{l}\text { Negative } \\
\text { Positive } \\
\text { Positive }\end{array}$ & $\begin{array}{l}1100 \\
3200 \\
2500\end{array}$ & $\begin{array}{l}\text { NT } \\
540 \\
710\end{array}$ & $\begin{array}{l}\text { NT } \\
510 \\
560\end{array}$ & $\begin{array}{l}\text { NT } \\
1 \cdot 10 \\
1 \cdot 30\end{array}$ \\
\hline $\begin{array}{l}\text { Partner } \\
1983 \\
\text { August } 1984\end{array}$ & $\begin{array}{l}\text { NT } \\
\text { Positive }\end{array}$ & $\begin{array}{l}\text { NA } \\
1200\end{array}$ & $\begin{array}{l}\text { NA } \\
290\end{array}$ & $\begin{array}{l}\text { NA } \\
440\end{array}$ & $\begin{array}{l}0.80 \\
0.65\end{array}$ \\
\hline $\begin{array}{l}\text { Controls } \\
\text { mean (SD) }\end{array}$ & Negative & $2100(330)$ & $930(230)$ & $410(100)$ & $2.40(0.55)$ \\
\hline
\end{tabular}

ARV = AIDS associated retrovirus; $\mathrm{NT}=$ not tested; $\mathrm{NA}=$ not available.

*Onset of symptoms in June 1985. 
On the basis of this report, we recommend covering any skin lesions that might be exposed directly to body fluids or persons with or at risk of infection with ARV. It would be prudent for anybody engaging in brachioproctic eroticism to wear latex gloves.

\section{References}

1. Barre-Sinoussi F, Chermann JC, Rey F, et al. Isolation of a T-lymphotropic retrovirus from a patient at risk for acquired immune deficiency syndrome (AIDS). Science 1983;220:86871.

2. Gallo RC, Salahuddin SZ, Popovic M, et al. Frequent detection and isolation of cytopathic retroviruses (HTLV-III) from patients with AIDS and at risk for AIDS. Science 1984; 224:500-3.

3. Levy JA, Hoffman AD, Kramer SM, et al. Isolation of lymphocytopathic retroviruses from San Francisco patients with AIDS. Science 1984;225:840-3.

4. Zagury D, Bernard J, Leibowitch J, et al. HTLV-III in cells cultured from semen of two patients with AIDS. Science 1984;226:449-51.

5. Groopman JE, Salahuddin SZ, Sarngadharan MG, Gonda M Sliski A, Gallo RC. HTLV-III in saliva of people with AIDSrelated complex and healthy homosexual men at risk for AIDS. Science 1984;226:447-9.

6. Thiry L, Sprecher-Goldberger S, Jonckheer T, et al. Isolation of AIDS virus from cell-free breast milk of three healthy virus carriers. Lancet 1985;ii:891-2.

7. Fujikawa LS, Salahuddin SZ, Palestine AG, Masur H, Nussen Blatt RB, Gallo RC. Isolation of human T-lymphotropic virus type III from the tears of a patient with the acquired immunodeficiency syndrome. Lancet 1985; ii:529-30.

8. Goedert JJ, Sarngadharan MG, Biggar RJ, et al. Determinants of retrovirus (HTLV-III) antibody and immunodeficiency conditions in homosexual men. Lancet 1984;ii:711-6.
9. Redfield RR, Markham PD, Salahuddin SZ, Wright DC, Sarngadharan MG, Gallo RC. Heterosexually acquired HTLV-III/LAV disease (AIDS related complex and AIDS). Epidemiologic evidence for female-to-male transmission. JAMA 1985;254:2094-6.

10. Curran JW, Lawrence DN, Jaffe $\mathrm{H}$, et al. Acquired immunodeficiency syndrome (AIDS) associated with transfusions. N Engl J Med 1984;310:69-75.

11. Lederman MM, Ratnoff OD, Evatt BL, McDougal JS. Acquisition of antibody to lymphadenopathy-associated virus in patients with classic haemophilia (factor VIII deficiency). Ann Intern Med 1985;102:753-7.

12. Friedland GH, Harris C, Butkus-Small C, et al. Intravenous drug abusers and the acquired immunodeficiency syndrome (AIDS). Demographic, drug use and needle-sharing patterns. Arch Intern Med 1985;145:1413-7.

13. Rubinstein A, Sicklick M, Gupta A, et al. Acquired immunodeficiency with reversed $\mathrm{T} 4 / \mathrm{T} 8$ ratios in infants born to promiscuous and drug-addicted mothers. JAMA 1983;249:2350-6.

14. Stewart GJ, Tyler JPP, Cunningham AL, et al. Transmission of human T cell lymphotropic virus type III (HTLV-III) by artificial insemination by donor. Lancet 1985;ii:581-4.

15. Anonymous. Needlestick transmission of HTLV-III from a patient infected in Africa. Lancet 1984;ii:1376-7.

16. Ziegler JB, Cooper DA, Johnston RO, Gold J. Postnatal transmission of AIDS-associated retrovirus from mother to infant. Lancet $1985 ;$; $896-7$.

17. Sydney AIDS Study Group. The Sydney AIDS Project. Med J Aust 1984;141:569-73.

18. Cooper DA, Gold J, Maclean P, et al. Acute AIDS retrovirus infection. Definition of a clinical illness associated with seroconversion. Lancet 1985; i:537-40.

19. Nicholson JKA, McDougal JJ, Jaffe W, et al. Exposure to human T-lymphotropic virus type III/lymphadenopathy associated virus and immunologic abnormalities in asymptomatic homosexual men. Ann Intern Med 1985;103:37-42.

20. Jeffries E, Willoughby B, Boyko W, et al. The Vancouver lymphadenopathy-AIDS study: 2. Seroepidemiology of HTLV-III antibody. Can Med Asoc J 1985;132:1373-7. 